\title{
EKPHRASIS IN ARTS AND WONDERS BY GREGORY NORMINTON:GIUSEPPE ARCIMBOIDO AND TOMMASO GRILLI
}

\author{
Harmash Liudmyla \\ Doctor of Science in Philology, Professor \\ ORCID ID 0000-0002-8638-3860 \\ H.S. Skovoroda Kharkiv National Pedagogical University \\ 29, Alchevskyh St, Kharkiv, 61002, Ukraine \\ garmash110@gmail.com
}

\begin{abstract}
Annotation
The article reveals some features of postmodern aesthetics that were borrowed by modern literature from romantics, and are now undergoing a period of criticism. It is shown how a fiction reflects the continuity between contemporary literature and previous literary phenomena, which consists in the perception, transformation, and critical rethinking of aesthetic ideas and concepts. For this purpose, the genesis of Norminton's novel Arts and Wonders was traced and a literary technique such as ekphrasis, that means a verbal description of a painting, was researched. An analysis of the two most significant ekphrasises - Vertumn and The Librarian - showed that the author of the novel raises the problem of copy or plagiarism, which today has gained particular relevance both in the world of art and in the academic environment. It was showed that Norminton solves this issue by referring to the traditional concept of mimesis. Despite the declaration of the need to imitate nature, Arts and Wonders demonstrates that the contemporary author asserts his right to free creative imagination, including the interpretation of historical facts and figures. The literary text refers to the artifacts which are presented in the arsenal of culture that are freely combined according to a kaleidoscope principle.

Raising the question of the dialectical unity of such aesthetic categories as "beauty" and "ugliness", Norminton enters into a polemic with the forerunner of postmodernism - romanticism. At the same time, the writer also poses questions about the correlation in the artist's work of parts and the whole, about the need to achieve a balance of proportions between the elements that make up a work of art. Determining the genre originality of the novel, the author of the article concludes that it is a complex synthetic form that combines the features of picaresque novel, a biographical novel, a travel book, a historical novel, an artist's novel, and a Bildungsroman, which as a result forms a new genre variety - an adventure novel about the artist.

Key words: ekphrasis, Norminton, Arts and Wonders, mimesis, plagiarism, kaleidoscope principle, adventure novel about the artist.

\section{Introduction}

In recent decades, artists, writers, poets, musicians become main characters of modern novels. I mention just a few of the most famous works written by authors living in different countries. These are such novels as The Goldfinch by Donna Tartt (USA), The Master of Petersburg by J. Coetzee (Republic of South Africa), Perfume: The Story of a Murderer by Patrick Suskind (Germany), The White Dove of Cordoba and the trilogy The Yellow Canary by Dina Rubina (Russia), Girl with a Pearl Earring and The Lady and the Unicorn by Tracy Chevalier (USA-UK), The Children's Book by A.S. Byatt (UK), and finally, Arts and Wonders by Gregory Norminton, which is the subject of our research. Postmodernism, whose representatives are the majority of the writers we have named, is a logical continuation of the traditions laid down by romantics at the turn of the 19th century. Previously, such a hero existed only in ancient mythology. The greatest honor was given to
\end{abstract}

(C) Harmash L., 2020 
the god Apollo, the patron saint of arts, who delighted the hearing of other gods with his dances, singing and playing a lyre or a kithara. Orpheus was widely known as a brilliant poet and musician. People, gods and nature obeyed the magical power of his art. He was the only mortal human being who was able to infiltrate Hades and return from there. Legendary poets of antiquity as Ibycus or Arion were also very popular characters of poems, works of art, etc.

Later, kings and military leaders, rogues and adventurers, wanderers and scientists became the heroes of literary works, but the artist in the broad sense of the word ceased to interest writers until the end of the 18th century, when Goethe's books about Wilhelm Meister (the early version of them had a significant title - Wilhelm Meisters theatralische Sendung or Wilhelm Meister's theatrical show) and Ernst Theodor Amadeus Hoffmann's novels about Johannes Kreisler appeared. The triumphant return of the artist to the forefront of culture was due to the increased interest of romantics in creative individual. The basis of their aesthetics was the category of imagination. The desire to reveal their inner world and to convey the fullness of feelings and emotions, as well as to recreate a "landscape of a poet's soul" were their main intents. Since then, the hero-artist has been one of the most popular literary types, e.g., A Portrait of the Artist as a Young Man by James Joyce or The Master and Margarita by Mikhail Bulgakov.

Various works of art, both real and fictional, are used in these novels. Different kinds of literary descriptions of the works of artists are usually called ekphrasis. The purpose of this article is to examine the features, types, and functions of ekphrasis in Arts and Wonders by Gregory Norminton.

\section{Materials and research methods}

Gregory Norminton (1976) is a modern British writer who is known to the general public and criticized for his first novel, The Ship of Fools. Arts and Wonders is his second novel. It was written in 2003, and in it the author continues to develop the creative principles that were used in the previous work, including the technique of ekphrasis. This novel is written on behalf of a fictional character, an artist Tommaso Grilli, who sets out his life story in it. The genre is a confession, a model for which could be the stories of such famous cheaters as Lazarillo de Tormes or Gil Blas (Shamina, 2016: 305). But we would not hastily assign the work of Norminton to the genre of a "novel of culture" only on the basis that it mentions many works of art (Ibid.). It is obvious that the main problem of Norminton's novel is the problem of simulation, imitation, copying and creating virtual reality. For example, the protector of the protagonist, Duke Albrecht, the head of the fictitious Bavarian principality of Felsengründe, is trying to imitate Emperor Rudolph II, even though he had never seen the latter. Not realizing that he can only become a pale and short-lived copy of his idol, Albrecht not only takes his middle name Rudolph, but spends the biggest part of his fortune on the Library of Arts, which mainly consists of copies of famous painting masterpieces fabricated by Tommaso. And Tommaso himself, as Shamina correctly noted, "becomes the grotesque simulacrum of Arcimboldo" (Ibid.).

An intermediate method of research is used in the article as the main approach to the study of the interaction of literature and painting. The methodological basis of the work is works of O. Hanzen-Löve, Bochkareva and other scientists who have studied the types, functions and methods of organizing ekphrasis in literary texts (Hanzen-Löve, 1983; Bochkareva, 2004, 2009).

\section{Discussion. A few words about ekphrasis}

Despite the wide popularity of The Ship of Fools, Norminton's other works, including Arts and Wonders, did not receive the resonance that, in my opinion, they deserve. There are only a few articles where have been noted such features of the novel as carnivalization, resemblance Normonton's work to picaresque and historical novels, myth of the Renaissance Man (Baratova, Shamina, 2018; Krjučkova, 2012; Shamina, 2016). The constant appeal of the writer to ekphrasis was noted by Shamina who has analyzed a 
structure-forming function of ekphrasis, that is "the basic principle, on which the whole novel is built" (Shamina, 2016: 303). But, in fact, the analysis of the functions of ekphrasis is suspended in this point. However, due to a wide number of ekphrastic descriptions in the novel and their diversity, their analysis must be continued, which we are going to undertake in this article.

Before proceeding to a direct analysis of the text, it is necessary to make a brief review of the literature on ekphrasis. The concept "ekphrasis" is origin from ancient Greece. In a broad sense, ekphrasis was used as a verbal description that contained such vivid images and had such a strong effect on the audience that listeners (or readers) could mentally imagine the subject as if they had seen it in reality (Braginskaya, 1977: 259). Gradually, the meaning of the concept narrowed and only artefacts become the subject of verbal description, as was the case with the works of Philostratus or Callistratus. In modern literary criticism, the understanding of ekphrasis in the narrow sense is more common (Philostratus, Callistratus, 1996). Many scientists believe that ekphrasis is a verbal description of a work of art. Perhaps the most famous example of ekphrasis is the description of the Achilles's shield in Iliad by Homer (Becker, 1995). However, today such an understanding of ekphrasis does not satisfy all researchers who have proposed to consider as an ekphrasis any literary description of a work related not only to the visual arts, but also to music, architecture, etc. S. Labre and P. Soler give the following definition of ekphrasis: this is "a decorated description of a work of art within the narrative, which it interrupts, constituting an apparent retreat" (quoted from: Geller, 2002: 5). This explains why some researchers appeal to the study of precisely pictorial ekphrasis. For example, Bochkareva has analyzed the different functions of ekphrasis (narrative, compositional, parodical, meta-narrative, erotic, allegorical, aesthetic, didactic, plot) in the novel The Ship of Fools (Bochkareva, 2009). The artist is a central character in Arts and Wonders and in Ghost Portrait, and the author made it intentionally. In one of his interviews, Norminton emphasizes that all these novels form a single cycle: "I regard my first three novels as a kind of trilogy, with painting as the uniting theme" (Karpos-Dedukhina, 2006).

\section{Genre Originality of the Novel and Polemic with Romanticism}

The novel Arts and Wonders paradoxically combines the genres of a picaresque novel, the classic form of which developed in Spain and was actively expanded in European literature between the 16th and 18th centuries, a biographical novel, a travel book, and a historical novel (the genre to which Norminton belongs very skeptical as we see from his interview (Karpos-Dedukhina, 2006)) and an artist's novel (in German: Künstlerroman). The last genre began to arrange in the Middle Ages, but in a classical form was presented in Wilhelm Meister's Apprenticeship by Goethe. Herbert Marcuse has related an artist's novel to a Bildungsroman and distinguished two types of this genre: the first one is realisticobjective and the second one is romantic (Marcuse, 2004). However, it is necessary to add one more to these types - an adventure novel about an artist which has developed in postmodernism. And Norminton's work is one of the best examples of such genre. The main character of his novel is an artist whose life path is quite twisty. the novel takes place in the late 16th - early 17th century. This historical period is known as Reformation when numerous wars broke out in Europe, including Thirty Years' War which fought in Central Europe (1618 - 1648) and the Battle of White Mountain (1620). Although, these historical facts and real personalities of the time, for example, a famous Italian painter Giuseppe Arcimboldo (1527 - 1593) who was known for his portraits made of different objects such as books, vegetables, flowers, fruits and fish, or Holy Roman Emperor Rudolf II (1552 1612). Norminton has stated that despite of the novel Arts and Wonders «touches on real events, the central characters are invented and their dilemmas apply equally to our own age» (Karpos-Dedukhina, 2006).

The writer's position correlates with the principles of postmodernism, according to which the author uses historical events and personalities as a material for creating a literary plot, but has the right to neglect the historical authenticity that realist writers so longed for. In a postmodern novel, fiction and creative fantasy become fundamental categories that can 
be regarded as reality, and the mimetic (imitative) function of art is rejected. A literary text is no longer perceived as a reflection of the real world or, using a metaphorical designation of the relationship between nature and the world of artifacts, as a mirror. It is not addressed to the reality immediately, but to other texts, and Arts and Wonders clearly demonstrates this view of fiction. On the one hand, the idea of copying and fakes presented in the book exposes the secondary nature of postmodernism. On the other hand, Norminton's novel is clearly polemicizing with the aesthetics of romanticism, according to which the artist is a sublime, spiritual person, endowed with a finely sensitive mental organization, which makes him strikingly different from ordinary people. His whole life is subordinated to a higher idea, he is not interested in earthly, mundane reality, since all his thoughts are aimed exclusively at achieving a connection with a spiritual Absolute. His appearance is completely inconspicuous or repulsive, but his inner world contains infinite spiritual wealth. Thus, such favorite technique of romantics as a contrast only emphasizes the inner nobility of the creative person. However, this cannot be said about the main character of Norminton's novel. Tommaso Grilli, as we have already mentioned above, is an artist, and his appearance not only cannot be called attractive, he looks disgusting. Here is how Tommaso describes himself referring to the reader of his "memoirs":

"My face, I'll grant you, was a disaster from the outset; but my limbs, at birth, must have seemed promising enough. Alas, deprived of affection, like a plant of water, I put forth unlovely shoots. That is to say that nothing grew in proportion. My anatomy is a hotchpotch, a fusion of parts from unequal models. Thus my legs, which a plum and hairy like a faun's, hunker down to narrow martyred feet. My upper torso is fully developed, with a ribcage that juts pompously forward, giving me the appearance of being trapped for ever at the summit of a sigh; yet my hips are narrow, balanced on chunky thighs, and my buttocks are childishly pert. (In some places I am better endowed. My manhood, for what it's worth, is short but uncommonly thick, and I have big hands that look like paddles on the ends of short, dimpled arms.) But how can you assemble this jumble of parts into a unified whole? As for my face, will not a list of features (a lush's nose, a weak chin, a tongue too big for its cave) merely confuse your mental picture and set lumbering through this book a gruesome composite, the impossible invention of a fevered brain?" (Norminton, 2004: 7). All this description can be regarded as an allegorical picture of a postmodern culture, distinguished by eclecticism which is, as the author of the novel has said, a product of "raving mind" (Karpos-Dedukhina, 2006).

One of the distinguishing features of Norminton's work, which allows us to attribute it to the genre of ekphrasis, is that the main character is surrounded by artists and is dedicated to the secrets of their art, into which the storyteller devotes the reader step by step. For example, when describing the learning process of drawing by Tommaso, specific terms, such as the names of paints, the process of preparing materials for drawing, drawing lines and their corrections, and others, are mentioned: Tommaso "learned to fix lines with ink, how to shade folds with washes and to erase errors using the soft of bread rubbed between finger and thumb. Then there were parchments to be prepared, and the monotonous tinting of paper with terre verte and white lead, with beans if vermilion and bone dust" (Norminton, 2004: 12-13).

The second important feature of the novel is the perception of the world and people as artifacts, i.e. the narrator is much less interested in reality as such and perceived is as if it were a sculpture or a picture. For example, Tommaso mentions that because of his unattractive, even ugly appearance, his relatives perceived him "like a bad painting made in his dotage by a great master" (Norminton,2004: 9).

Thus, the appearance of a child is judged not as a living creature, but as an image on a canvas, thereby drawing an analogy between the artist and the Creator, which was characteristic of Renaissance thinking. And despite the fact that the creator of the protagonist "fell into insanity" and the picture turned out bad, the narrator calls his creator "a great master", which makes the hint completely transparent and easy to understand. In the same vein, the narrator describes the letters when he informs the reader that for some 
time his last name began to be written a little differently, because "That my family name (having lately shed the blooming -o for -i's barren stem) signified anything so apt was depressing news" (Norminton, 2004: 26),

The third feature of the novel is the drawing of clear parallels between plot twists and turns, reflecting cardinal changes in the fate of the protagonist, and the device of the artist's workshop, which, in turn, is compositionally organized and has a central focus, as if it obeyed the rules of the Renaissance perspective. So, when Tommaso once again comes to his father's workshop to improve his artist's skills, he describes it as follows: "Unbidden, I assumed my place at my work stool. From having tiptoed past my father's studio, I was now its focal point, the axis upon which all things revolved", which gives him reason to conclude that a "sharp turn" has occurred in his fate. (Norminton, 2004: 13)

Further development of events becomes the realization of an artistic metaphor, the trajectory of the hero's fate obeys the rules of organizing the space of a classic work of art.

\section{Ekphrasis \# 1. Vertumn}

The birth of Tommaso became the cause of his mother's death and his father did not want to take care of him. Only once, despite Tommaso's outward ugliness, his father showed his love. It happened when he noticed extraordinary abilities of Tommaso as a painter and asked Arcimboldo to teach his son. The choice of Arcimboldo as a teacher is extremely significant and eloquent. This Italian artist really worked for Rudolf II in Prague and, as was customary at that time (it can be compared with the Renaissance universalism of Leonardo to Vinci), performed the duties of not only a painter, but also a decorator, party organizer, engineer, and collected works of art. He became famous for his unusual portraits, the compositions of which were created from plants, animals, figures of people or various objects. Roland Barthes has noted that they make a double impression on the viewer combining disgust and admiration (Barthes, 1985: 139-148). Then public forgot about painter's experiments till the 20th century when surrealists became to regard Arcimboldo as their predecessor and nowadays his work not only regained its former glory, but also increased it.

To begin with, even the appearance of Norminton's hero (see the quotation above) is described in accordance with the rules that Arcimboldo guided, composing pis paintings to connect the incompatible. However, if Arcimboldo succeeded in achieving integrity and even undeniable portrait similarity, as can be seen in the portrait of Rudolf II, this does not happen with Tommaso. It happened because one of the principles of aesthetics discovered in ancient Greece is violated: first of all, harmony suggests the proportionality of the individual parts from which the work of art is formed (hence the constant search by artists for ideal proportions).

Like his teacher, who participated in the creation and replenishment of the famous collection, named The Kunstkammer of Rudolf II and located in Prague, Tommaso Grilli built for his patron, the Duke Albrecht Rudolfus, an art library in which he placed works of sculpture, paintings, and various wonders, turning the library into a mysterious labyrinth.

The acquaintance of Tommaso and Arcimboldo is described in the first part of the novel, entitled Monstrorum Artifex (Monsters Artist). So, Arcimboldo is showed as a creator of fantastic grotesque creatures - monsters. The first meeting takes place by chance in the Milan Duomo in front of the statue of St Bartholomew. Tommaso and Arcimboldo are interested in the question of how the sculptor managed to convey the structure of the body, all his muscles and veins with the utmost accuracy. They talk about changes that have occurred in the approach to the study of nature in the Renaissance comparing with the Middle Ages. Artists turned from contemplators into experimenters who studied the human body with the thoroughness of an anatomical scientist. At the same time, Arcimboldo recalls one of the most famous Renaissance artists - Michelangelo, whose self-portrait, as many critics suggest, is the image on the skin of St Bartholomew, depicted in the fresco The Last Judgment in the Sistine Chapel. 
During a second meeting in front of the cathedral Arcimboldo learns that Tommaso is a self-taught artist. The great painter invites Tommaso to his house, where the latter gets the opportunity to see the portrait of the emperor as Vertumn. Before proceeding to the description of the picture, the narrator depicts in detail the unusual home of the artist. It was explained, firstly, by the fact that he avoided sunlight, therefore darkness reigned in the room, and the objects located there could be seen only in the faint flickering of candles. Secondly, the meeting with the picture is preceded by a description of fruits and flowers, from which, in fact, the portrait was made: "There was a buzzing of flies, and I glimpsed in the rare spots of daylight decaying fruit, a yawning lily, roses on the turn. It was difficult to see where I placed my feet. Grapes burst between my toes. I crushed an apricot and nearly skidded" (Norminton, 2004: 27).

The floor was literally strewn with disgusting remains of plants and it sharply contrasted with the magnificence of the portrait itself. Nature here gives way to culture, being only material that is used to make the perfect creation of human hands, and then ruthlessly thrown away. After describing the room's atmosphere, the focus of attention shifts to the artist himself, whose appearance paradoxically combines the features of animate and inanimate, frozen face masks and spiritualized gaze: "He looked like a wax effigy, a depiction of the magus; but his eyes shone with childlike ardour" (Norminton, 2004: 27). Tommaso managed to see the masterpiece that was not yet completed, which became known from Arcimboldo's commentary: "Very nearly finished,' he said. 'Just the nose and the chin. The chestnuts are no good. Half rotten. I'll improve them from memory" (Norminton, 2004: 27-28).

Next part of the ekphrasis is a description of the picture seen through the eyes of the protagonist, who is trying to simultaneously convey his impression. Of course, the modern reader knows about this painter and his works, but Tommaso begins the description with an appeal to his contemporaries, who hardly remember Arcimboldo. Here the writer follows historical facts, which say that despite the huge number of imitators, the artist had been forgotten for a long period of time, and glory returned to him only in the 20th century. From an exclamation addressed to readers and conveying regret that they will not be able to enjoy the magnificent work of art, the narrator also mentions the name of the deity and gives his brief presentation. After that he proceeds to the description of Vertumn. First of all, his attention is attracted by blackberry eyes, then his focus slides downward, passing successively to peaches (cheeks), cherries (lips), a neck, a chest, an onion clasp, and a flower shirt. He then conveys his admiration, calling the portrait "a feast for the eyes." (Norminton, 2004: 27) The culinary metaphor is especially relevant, as the portrait is basically composed of products usually served on the table during the meal. A couple more details is mentioned in the completion of this description - a crown of spikelets and a mustache. And finally, a statement of portrait similarity is ending this fragment. The following is an ekphrasis of Arcimboldo's painting:

"Alas, you that know nothing of a neglected painter will have no conception of that wondrous being, Vertumnus, the Etruscan god of bounty. He stared at me with blackcurrant eyes: animate, mythical and fainty malevolent. His cheeks were peaches and his lips red cherries. Marrows, aubergines and a radish constituted his throat and chest, to which a gown of flowers was pinned by an onion clasp. But my words are blind: a feast for the eye cannot be matched by ten volumes of prose. Crowned with fruits of the harvest, with hazelnut husks for a moustache, it was a dazzling conceit and somehow familiar, in the way of masterpieces." (Norminton, 2004: 28)

Then the narrator transmits his conversation with the painter, they discuss topics related to aesthetic problems that artists, philosophers and all who have one or another relation to art, have been trying to solve for many centuries - the relationship between parts and the whole in painting, the dialectical unity of such aesthetic categories as "beauty" and "ugliness", and the problem of mimesis.

Tommaso was delighted with the painting by Arcimboldo because being made up of completely different parts, it turned into a portrait of a man, accurately conveying his 
appearance and character: "Each grape and marrow and ear of corn was carefully rendered as itself; yet each part belonged to the unified whole" (Ibid.).

Compare it with the description of Tommaso's appearance, which we quoted earlier. Describing each part of his body individually, the narrator notes with chagrin that they have remained a "heterogeneous hash". There is no harmony between individual elements, they are connected unsystematically and do not add up to unity. And here, in our opinion, the author of the novel turns to one of the basic principles of ancient aesthetics, which stated that harmony arises only if all parts of the subject are proportionate to each other.

In the ancient world, much attention was paid to proportions. They reflected the basic laws of the universe - the cosmic order. And if we compared the system of proportions that Vitruvius wrote about in his multi-volume work known as "De architectura" or Polykleitos' Kanon with what Tommaso looked like, it would be obvious that his appearance did not meet a single rule of harmony that ancient philosophers and artists claimed. François Blondel who was the famous French architect of the 17th century said: "The satisfaction that we experience looking at a beautiful work of art stems from the fact that the rules and measures are observed in it, because only proportions are the source of our pleasure." (cited from: Voloshinov, 2000: 208) In the competition between nature and the artist, the latter won. If nature failed creating Tommaso then Arcimboldo achieved undeniable success. He was able to combine in his works individual elements, which were exact copies of natural objects, into unity. Moreover, every single detail of the artist's paintings evokes a feeling of disgust from a viewer (a viewer in the novel is equal a narrator), as Roland Barthes accurately noted in his article Arcimboldo: Monsters and Miracles. He admitted that if you look closely at the image, it turns out that "Arcimboldesque flesh is always excessive: either ravaged, or flayed (Herod), or swollen, or sunken, dead." (Barthes, 1985: 145) However, the monstrosity of each individual part turns into a miracle when they join together, obeying the artist's ingenious intuition. Arcimboldo's friend, a poet Don Gregorio Comanini in his poem on the painting of Emperor Rudolf II as Vertumnus wrote about the dialectical unity of opposites (visible and hidden) in the portrait:

Though my aspect may be monstrous,

I bear noble traits within.

Hiding thus my kingly image.

Tell me now if your are willing

To discern what I conceal:

Then my soul I will reveal (Kriegeskorte, 2000: 46).

Thus, at the end of the 16th century, the artist and the poet turned to one of the favorite topics that romantics who loved to create characters that hid noble features under an inexpressive or ugly appearance would discuss passionately.

Imitating nature, Arcimboldo transformed it into something completely new that did not exist before, and at the same time achieves undoubted portrait resemblance to Rudolf II who liked the portrait so much that the artist was awarded an honorary title Pfalzgraf. This is explained the emperor's love for everything outlandish. It is also important that Vertumn was the god of metamorphoses, the change of seasons and other transformations. He could change his form, as, for example, is described in Ovid's Metamorphoses (XIV), when he took the form of an old man to deceive Pomona. Furthermore, this is closely connected with the motif of alchemical transformations in Norminton's novel. Arcimboldo draws Tommaso's attention to this fact, saying that "Vertumnus was also the god of Metamorphosis, He could assume any form he chose" (Norminton, 2004: 28).

The god metamorphosis is an allusion to numerous anthropomorphic myths about the emergence of the world from parts of the first man, which Comanini mentioned when he described Arcimboldo's work:

And its face is called Olympus, 
Eyeing us with many stars,

Air's the chest, and Earth the belly.

Mountain valleys are its feet,

And the soul which warms and quickens

And enlivens this great body

Is the element of Fire;

Clothed in produce of the earth,

Wearing plants and fruit and grass (Kriegeskorte, 2000: 45).

According to the poet, Vertumn gives life to heavenly bodies, generates the primary elements of the cosmic universe (air, fire and earth), thereby referring the reader to such myths as the Chinese myth of Pangu. After the death of this god "his breath became the wind, mist and clouds; his voice, thunder; his left eye, the Sun; his right eye, the Moon; his head, the mountains and extremes of the world; his blood, rivers; his muscles, fertile land; his facial hair, the stars and Milky Way; his fur, bushes and forests; his bones, valuable minerals; his bone marrow, precious jewels; his sweat, rain; and the fleas on his fur carried by the wind became animals." (Shri Bhagavatananda Guru, 2015: 129) Or to another myth about Ymir (also called Aurgelmir) - in Germanic-Scandinavian mythology the first living creature, a frosty giant from whom the world was created. And other similar examples are known well. It is interesting that Norminton's work refers to this characteristic of Vertumn, but in a novel it symbolizes the reverse transformation from a natural creature into a cultural hero, being a mirror reflection of ancient mythology. In this sense, Norminton's Vertumn develops the theme of copies and simulacra which characterize of postmodern culture. Arcimboldo in his work establishes a relationship, on the one hand, between nature and man, on the other hand, between man and God, which corresponds to the idea of the likeness of macrocosm and microcosm, man and the Universe.

The concept of mimesis, which originated in ancient Greece, is also connected with it. Philosophers Plato and Aristotle concerned that mimesis represented nature. But according to Aristotle, art surpasses nature because the last one is full of change and decay, and therefore it is inferior to art that obeys mathematical laws in the search for the perfection and embodies the essence of all things. This idea of art is literally expressed in this scene of the novel, where the perfection of the picture is contrasted with decaying fruits and flowers that cover the entire floor of the workshop, so the artist is forced to draw some parts of the portrait from memory. Arcimboldo expresses this idea, sharing the secrets of his skill with Tommaso: "'For the fabulous image to convince the viewer,' said Arcimboldo, 'let its parts be copied faithfully from Nature. It is detail which gives life to an object. If you wander too far from Nature, nothing you paint will please" (Norminton, 2004: 28).

This statement is correlated with the central dilemma of the novel between the copy and the original. In a novel originality is achieved by careful copying of individual elements of nature. Tommaso is convinced of this by comparing a bunch of cranberries and its image: "The copy was perfect, right down to the twin leaves and the number of berries" (Norminton, 2004: 28). At the same time, Tommaso, being a skilled copyist, remains just an imitator, and his attempts to create original canvases fail.

\section{Ekphrasis \# 2. The Librarian}

The portrait of Albrecht Rudolphus was to be a triumph of Tommaso as a copyist. He intended to draw it in the manner of Arcimboldo, trying to repeat very accurately even the environment of Arcimboldo's work place. The great painter preferred twilight and used candles to illuminate his models, and Tommaso was completely sure that in this competition he, the student, would surpass his teacher. And here again the question about the superiority of the artificial portrait over nature is raised: "The painting would no more be a mirror of surface reality than the portrait of the Emperor had been when Arcimboldo transformed him into the Etruscan god harvests" (Norminton, 2004: 181). 
A meticulous reader of the novel can easily make sure that such a portrait really exists, but it belongs to Arcimboldo. Since the picture is not fictional, it is possible to compare its literary description and pictorial original, as well as to compare two ekphrasises - The Librarian and Vertumn. The narrator begins to describe these paintings in different ways. When it comes to a portrait of Rudolph, the eyes are the first to be mentioned, because they are the central, most significant part of the image of a person's face. In the case of The Librarian, the narrator begins the description of the future picture from the periphery - a curtain thrown over the model's shoulder, and then from all the features of the model's appearance only mentions disgusting warts and flaws, while emphasizing that he thoroughly studied the smallest details of Albrecht's appearance. He also informs reader about his artistic task: "I needed less the particulars - that patent constellation of warts and blemishes - than the gist of a likeness, a graspable impression of Albrecht Rudolphus" (Ibid.). So, he tries to reflect the image of a real person in a painting to create the illusion of the identity of nature and artifact. The theme was chosen with a clear intention not only to plausibly convey the resemblance, but to express the very essence of Albrecht's character, who was a passionate collector of paintings, antiquities and various monstrous miracles. After the artist made several quick sketches, he freed the model from posing, then a short digression follows. Reporting on how the artist selects the appropriate material and "composes" the composition of the future masterpiece - and the artist has no doubt about this, as follows from his own assessment of his work - in essence, he describes the real picture of Arcimboldo, practically without retreating from reality: "Work began on the stretching out and grounding of a canvas; paints were mixed to pre-determined colours. I planned to fuse my studies of the Duke's face with my elaborate conceit. I arranged twenty or so books of diverse sizes - some of white calfskin with gold filigree engraving, others with beige or red leather bindings - into a discernible shape on a table, and so began to trace the outline of a pyramidal torso". (Norminton, 2004: 182)

During his immediate work on the painting, Tommaso experiences an extraordinary creative upsurge, a huge impulse of inspiration that even physically transforms him, sharpening his perception, turning his body into a painter's brush and causing him to experience a powerful physical shock throughout my body: "My buzzing ears were attuned to every rasp of my hand on canvas - to the muted pealing of a water glass when I stuck it with my bleeding brush, whose stiff bristles found their echo-image in the short hairs that stood up on the back of my neck". (Norminton, 2004: 182) To emphasize the power of creative ecstasy experienced by the artist, Norminton compares it with a bolt of lightning: "Years later I would experience the same jolt of primary power when, upon the barren crest of a mountainside, a bolt of lightning grounded itself inches from my feet". (Norminton, 2004: 182) But as soon as Tommaso admits that he is talented, he refutes his ability as a painter. A whole paragraph of the text is reserved for his reasoning about his own failures, both as an original artist and as a falsifier of other painters' works.

The following episode of ekphrasis, devoted to the description of the head in the portrait, is done in extremely detail, especially compared to the description of Albrecht:

"Four brown leather volumes were used to represent the head, with a black ribbon undulating for eyebrows and two further ribbons, fortuitously catching an improvised light, doing service as the monster's eyes. A salmon-pink ribbon tied to the book of his cheek became the Librarian's left ear, while two small copies of Euclid represented plump lips emerging from a beard (flatteringly made fuller than the subject's own) of sable-tail dusters. An eighth book served as a long proboscis jutting on a diagonal from the face. It was impossible within such constraints to convey the human blemishes of the Duke, though I did brush in, as an afterthought, a red-buttoned clasp to suggest the wart that nestled alongside his nose. Finally I had only to solve the problem of hair. The greasy straw which seemed, for shame, so eager to escape the Duke's speckled scalp could find no counterpart in my caprice. My solution was to paint an open book (a ledger pilfered from the Treasury on account of its silk-beaded markers) resting on the impassive head. This ledger rounded 
off the stolid construction of the painting, rather as a dome or pages lent a bird's plumage to the effigy - a creamy crest which yet suggested the headgear of a scholar" (Norminton, 2004: 183)

Tommaso's story not only consistently describes the head of the "Librarian", accurately indicating the number, size, color and arrangement of books and bookmarks, but he also describes the process of creating the portrait and selecting individual details to convey the appearance of the model as accurate as possible. He focuses on two elements - a buckle painting a wart and dirty straw, which would be best suited for depicting model's hair and which the artist decided to replace with an open book. In addition, this description consists some hints of Tommaso's attitude towards his customer, in which flattery (a beard and hair) is combined with disgust (a wart).

This wart is noticed by Albrecht in the next episode of ekphrasis, which deals with his perception and evaluation of the portrait. Initial admiration for the artist's ingenuity is replaced by anger when Tommaso asks how he managed to convey the similarity of the image with the model. The duke is disappointed and angry, as he believes that there is no life in the picture, it is a "carrion" in which he does not see any resemblance to a human being at all.

The final episode of ekphrasis is devoted to the analysis of The Librarian and its comparison with Vertumn. Tommaso concludes that Albrecht was right:

"This seemed a brilliant forgery in Arcimboldo's manner; yet the Duke himself had Etruscan god had gleamed in the Mater's studio, fearfully alive, as though at any moment he might saunter into the breathing world. Something of humanity had survived, also, in that original painting - something of the Emperor. In my forgery no such spark of life existed. This was a grim portrait, the likeness if an automaton, an emissary from the Underworld of Dead Objects. No wonder Albrecht Rudolphus had hated it with such passion. The Librarian was a sterile being. Its books clasped shut, its eyes unseeing, it could breed nothing." (Norminton, 2004: 184)

So, the lifelike is stated as the main criterion for evaluating an artwork in Norminton's novel. If a viewer has the impression that a canvas is a reflection and continuation of reality, and only the invisible border between the two worlds is imaginary and real, if it seems that images of people can come to life at any time (Pygmalion's motif), then this work can be considered a masterpiece. Otherwise, it is regarded as a "mechanical likeness", a dead imitation of nature. This approach was especially popular in antiquity, when Zeusxis or Parrasius, according to a historical joke, painted a bunch of grapes so vividly that birds flew to peck it (Kun, 1954). However, such an assessment of a work of art has not been unique for a long time, and Johann Wolfgang Goethe said of critics who were convinced that this episode testifies to the artist's excellence: "Not at all, it rather proves to me that these amateurs of art were true sparrows" (cited from: Suzdalev, 1964: 5).

Thus, a complex ekphrasis consists of several alternating and interdependent levels: a description of the artwork, which is divided into three parts and moves from the periphery (curtain) to the general characteristic of the composition and after that to the center where the face of the model. It is supplemented by a narration about the artist's work on the painting with an emphasis on his inner statement at that time, which is characterized as a creative upsurge, on the perception and appreciation of the painting by the customer. The ekphrasis ends with the reasons for the creative failure, which lies, in the opinion of both the character and the author of the novel, in imitation, not endowing the picture, in contrast to original artworks, with the energy of life. Dramaturgically, ekphrasis is based on an alternation of emotional ups and downs, with a gradual increase in tension. The climax of the ecstatic plot is a negative assessment of the picture by the customer, followed by the denouement of the action when the artist admits his defeat.

If the original painting by Arcimboldo bizarrely combines beauty and ugliness, admiration and disgust, but the viewer is convinced of the artist's genius, because he 
managed to combine the individual parts into a wholeness, then ugliness does not transform into beauty in Tommaso's copy, despite all his efforts ${ }^{1}$.

\section{Conclusions}

Thus, in recent decades ekphrasis has become a widespread literary device, and one of the main reasons for this popularity is the genre of the novel about the artist, which writers of different countries turn to. An analysis of Norminton's novel as one of the most representative examples of this genre gives us reason to conclude that it was due to a postmodern reaction to romantic aesthetic principles, which, especially at the first stage of postmodernism development, were assimilated and supported, although they were mostly pushed into the field of mass cultures, and are currently undergoing a period of criticism and rejection. That is what we tried to demonstrate in this article considering Arts and Wonders as a vivid example of changes experienced by modern literature. An appeal to an artist's novel allowed Norminton to consider the extremely relevant problem of the ratio of an original artwork and its copy (fake), which correlates with the currently popular problem of plagiarism.

\section{REFERENCES}

Baratova, Shamina, 2018 - Baratova O.A., Shamina V.B. (2018). Metateatral'nost' v sovremennom angliiskom romane (na materiale proizvedenii B. Ansuorta «Moralite» i G. Normintona «Chudesa i dikoviny») [Metatheatre in Contemporary English Novel (Based on the Novels "Morality Play" by B. Unsworth and "Arts and Wonders" by G. Norminton)]. Uchenye Zapiski Kazanskogo Universiteta. Seriya Gumanitarnye Nauki, vol. 160, Nr 1, pp. 159-174 [in Russian].

Barthes, 1985 - Barthes R. (1985). Arcimboldo, or Magician and Rhetoriqueur. In Barthes R. The Responsibility of Forms. Critical Essays on Music, Art and Representation. Translated from the French by R. Howard, Hill and Wang: New Yorkm, pp. 129148 [in English].

Becker, 1995 - Becker A. S. (1995). The Shield of Achilles and the Poetics of Ekphrasis. Lanham, MD: Rowman \& Littlefield [in English]

Bochkareva, 2004 - Bochkareva N.S. (ed.) (2004). Ekfrasticheskie zhanry v klassicheskoi i sovremennoi literature: monografiya [Ekphrastic genres in classical and modern literature]. Perm.gos. nats. issled. un-t. Perm', 2014 [in Russian].

Bochkareva, 2009 - Bochkareva N.S. (2009). Funktsii zhivopisnogo ekfrasisa v romane Gregori Normintona «Korabl' durakov» [Functions of pictorial ekphrasis in the novel "The Ship of Fools" by Gregory Norminton]. Vestnik Permskogo Universiteta. Rossiiskaya i Zarubezhnaya Filologiya, Nr 6, pp. 81-92 [in Russian].

Braginskaya, 1977 - Braginskaya N.V. (1977). Ekfrasis kak tip teksta (k probleme strukturnoĭ klassifikatsii) [Ekphrasis as a type of text (to the problem of structural classification)] Slavyanskoe $i$ balkanskoe yazykoznanie. Karpatovostochnoslavyanskie paralleli, Moskva: Nauka, pp. 259-283 [in Russian].

Geller, 2002 - Geller L. (2002). Voskreshenie ponyatiya, ili Slovo ob ekfrasise [The Resurrection of the Concept, or the Word of Ekphrasis]. Geller L. (red.) Ekfrasis $v$ russkoi literature: trudy Lozannskogo simpoziuma. M.: MIK, pp. 5-22 [in Russian].

Hansen-Löve, 1983 - Hansen-Löve O. (1983). Intermedialität und Intertextualität. Probleme der Korrelation von Wort- und Bildkunst - Am Beispiel der russischen

${ }^{1}$ In 2003, Norminton was able to predict what art critics would come to in 2011 namely, that The Librarian, who is now kept in the Skokloster collection, is actually a fake. You can read more about this in the book by Frantisek Makes and Maria Brunskog who concluded that "The Librarian at the Skokloster Castle collection is a later copy of Arcimboldo's original painting, since the structure of the paint specimens from the Librarian are different and show different patterns compared with that of the Vertumnus." (Brunskog, Makes, 2011: 47). 
Moderne. Dialog der Texte. Hamburger Kolloquium zur Intertextualität. Hg. von W. Schmid und W.D. Stempel (Wiener Slawist. Almanach, Sonderb. 11). Wien, ss. 291-360 [in German].

Karpos-Dedukhina, 2006 - Karpos-Dedukhina E. (2006). Interview with Gregory Norminton. Book Review newspaper Knizhnaya Vitrina (October) https://proza.ru/2013/02/10/2030 [in English].

Kriegeskorte, 2000 - Kriegeskorte W. (2000). Giuseppe Archimboldo: 1527-1593. Ediz. Inglese Taschen [in English].

Krjučkova, 2012 - Krjučkova O.R. (2012). Mif «renesansnoji ljudyny» ta joho zaperečennja u romani G. Normintona «Dyva i čudasiji» [The myth of the Renaissance Man and Its Objection in Norminton's Novel Arts and Wonders]. Mova i kul'tura, Issue 15, Vol. 6(160), pp. 373-378 [in Russian].

Kun, 1954 - Kun N.A. (1954). Legendy i mify Drevnei Gretsii [Legends and myths of ancient Greece]. M.: State educational and pedagogical publishing house of the Ministry of Education of the RSFSR [in Russian].

Makes, Brunskog, 2011 - Makes F. Brunskog M. (2011). Enzymatic Restoration and Authentication of Giuseppe Arcimboldo's "Vertumnus". Gotland University [in English].

Marcuse, 2004 - Marcuse H. (2004). Der deutsche Kdnstlerroman. Frühe Aufstütze. Marcuse H. Schriften in 9 vol. Vol. 1. Frankfurt [in German].

Philostratus, Callistratus, 1996 Philostratus, Callistratus (1996). Filostrat. Kartiny. Kallistrat. Opisanie statui [Philostratus. Paintings. Callistratus. Description of Statues] Translation, introduction and examples by S.P. Kondratiev. Tomsk: Vodolei [in Russian].

Shamina, 2016 - Shamina V.B. (2016). Funktsii khudozhestvennykh artefaktov v romane kul'tury Gregori Normintona "Chudesa i dikoviny» [The functions of artefacts in the novel of culture "Arts and Wonders" by Gregory Norminton]. Filologiya i Kul'tura, Nr 2, pp. 303-307 [in Russian].

Shri Bhagavatananda Guru, 2015 - Shri Bhagavatananda Guru (2015). A Brief History Of The Immortals Of Non-Hindu Civilizations: In association with Aryavart Sanatan Vahini 'Dharmraj'. Createspace Independent Publishing Platform, United States [in English].

Suzdalev, 1964 - Suzdalev P.K. (1964). Osnovy ponimaniya zhivopisi [Basics of understanding painting]. Moskva: Iskusstvo, 1964 [in Russian].

Voloshinov, 2000 - Voloshinov A.V. (2000). Matematika i iskusstvo [Mathematics and Art] Moskva: Prosveshchenie [in Russian].

Text

Norminton, 2004 - Norminton G. (2004). Arts and Wonders, Kindle Edition [in English].

Received: 28 December, 2019 